\title{
MARADÉKOK BOLTJA \\ (Egy visszavonuló levelei)
}

\author{
Kedves B.!
}

Alábbi hevenyészett írásom nyolc éve született, már akkor is B.-nek címezve, aztán különbözỏ okok miatt - öncenzúra! -, ahogy mondani szokás, íróasztalom fiókjában maradt. Tán ott is marad végleg, ha kiváló pályatársunk, Probáld Ferenc nem jelenteti meg ugyanezen témáról írt gondolatait a Tér és Társadalom 2007. évi 1. számában, majd nem reagálnak ketten is, Enyedi György és Dusek Tamás e cikkre. (Nem mellesleg Mészáros Rezső is értekezett a földrajz és a regionális tudomány viszonyáról a Magyar Tudományban [2006./1.]) Úgy tủnik, a regionális tudomány és a geográfia viszonyáról felmerülö kérdések nem vesztették el aktualitásukat a regionális tudomány hazai intézményesülése, „megszilárdulása” után sem. Az alábbi néhány oldalt erős felindultságból követtem el - így nem is okadatoltam kellően -, nem érinti a kérdéskör jó néhány összetevőjét (a regionális tudomány kialakulásának okai, története, a két tudományág - vagy ágazat, terület, ki tudja - viszonyának magyarországi alakulása, a geográfia e kérdésben tanúsított passzivitásának oka stb.), mégis úgy döntöttem, eredeti formában, a 2000-ben írtakon mit sem változtatva adom közre, még akkor is, ha ma már talán „higgadtabban” - hja, 72 év! - fogalmaznék, s írásom néhány következtetése meg is egyezik Probáld Ferenc gondolataival.

Tehát:

\section{Kedves B!}

Engedd meg, hogy egy merőben szubjektív megjegyzéssel kezdjem soraimat. Beszélik, hogy Manuel Castells új háromkötetesét („Az információs kor”) elsősorban a hảlózatoknak szenteli, a hálózatoknak, melyek alapstruktúráját képezik a társadalom morfológiájának, a termelésnek, de a hatalom és kultúra múködésének is. $\mathrm{S}$ mindaz ill. mindazok lehetnek sikeresek, akik a lehető legközelebb kerülnek a hálózati csomópontokhoz - ahol a dolgok eldólnek -, ha már nem maguk alkotják a csomópontokat. Hallván eme bölcselmeket, mondtam magamnak; így hatvanon is túl már megjöhetne a józan eszem, ideje lenne jobb pozíciót kiügyeskedni a hálón. $\mathrm{Na}$, de milyen az ember, megint olyasmiröl hümmögök itt, ami - könnyen lehet - nem visz közelebb az áhított csomópont-közeli pozícióhoz. Most már nem Castellsel, hanem a „nép egyszerü fiával” szólva, megint magam alatt vágom a fát. (A ,nép egyszerü fia" mellesleg ezt markánsabban is meg szokta fogalmazni, de ennek betühív viszszaadása a szép- $\mathrm{s}$ nem a szakirodalom feladata.) 
De a lényegre, a regionális tudomány szárba szökkenése nyomán felvetődő néhány kérdésre.

Elöször: némi tudományelméleti (tudományfilozófiai?) közelítés: a társadalom mozgása nem szociológiai, közgazdasági, demográfiai stb. folyamatokból tevődik össze, hanem egységes folyam. Ezt az egységes „áramlást” bontja fel a tudományosság különbözo „részfolyamatokra”, megfigyelési egységekre, a tudományágak által magukénak vallott terrénumokra, kényszerüségbőll. Kényszerüségből, elismerve, hogy a véges egyes emberi elmék nem képesek felmérni, leírni, magyarázni e folyam (a társadalom állapota és mozgása) mindenfajta tulajdonságát, a folyamatot a maga összetettségében. Erre az antikvitásban még volt remény, történtek is reménykeltő kísérletek, majd jódarab ideje osztogatjuk az „utolsó polihisztor” címet, elismerve, hogy egyre reménytelenebb az össztudományok müvelése egyetlen elme részéröl. Aligha foglalkozhat valaki a siker reményében hétfön Kant kategorikus imperativusának kritikájával, kedden Rásonysápberencs helyi társadalmának szociológiai rétegeivel, szerdán összehasonlító nyelvészettel, csütörtökön az özönvíz motívumának felbukkanásával egyes népek hagyományában, pénteken jogdogmatikával, hogy a hétvégéről ne is szóljak. A társadalom életének eseményei tehát nem „bomlanak szét” az egyes tudományágak vizsgálta „részterületekre”, a valóságban nincsenek is valaminő hatások az egyes „aspektusok” között, ám kétségtelen, hogy a legegyszerúbb emberi (társadalmi?) cselekvés-sor analizálásához egy sor szakember szükségeltetik, akiknek persze megvan a maguk sajátos érdeklődési köre, szemlélete, módszere stb., ismétlem, kényszerüségből, ill. az emberiség egyik legnagyobb találmányának, a munkamegosztásnak köszönhetöen. (Nem akarom elviccelni a dolgot, de hát jelenjen meg elötted a kép, kedves B., amint fött paprikás tokaszalonnát vacsorálok, s ezen „eseménysor" értelmezéséhez tucatnyi társadalomtudós üli körül asztalom: a táplálkozástan tudósa szomorúan ingatja fejét a koleszterin-bomba láttán, a szociológus megkérdi, ugye, azért e szalonnázás, merthogy elsőgenerációs meg a rurális környezet a gyermekkorban, mire a közgazdász megjegyzi, hogy egy frászt, de az akadémiai fizetések meg a fogyasztói kosár, nálunk egy negyven éve dolgozó tudósféle hogy ehetne csirágfejeket csőben sütve lyoni mártással, a derék etnográfus meg megkérdi, errefelé a kies Fölsö-Vízivárosban e szalonnafajtát abált vagy abárolt szalonnának nevezik-é, bejelölendő ezt a Néprajzi Atlaszba. Én meg csak szalonnázom tempósan, népieschen). Így tehát a társadalomtudományok tudományszakokra való elkülönülése nem a „valóság leképezése”, hanem a praktikum diktálta, véletlenszerü és kényszerủ munkamegosztás, s tudományelméleti szempontból nem is igazán lényeges kérdés. Az oly gyakori határvillongások mögött többnyire pillanatnyi és parciális érdekek búzódnak meg. E határok relatív és esetleges voltát az ,interdiszciplináris" szavak szaporodása is jelzi. Akadémiánk kebelében a közelmúltban zajlott diszciplína-vita, a verejtékkel-könyökkel kialakított hierarchia, ill. az illetékességi területek szigorú kicövekelése a vázoltakat elfogadva legfeljebb elnézö mosolyt kiváltó játszadozás. Nincs tehát különösebb jelentősége az újabb jelzőkarók leverésének, az „illetékességek” deklarálásának, a diszciplináris hovatartozás betartásának. Újabban történeti-földrajzi témákkal is foglalatoskodom, de zavarban lennék, 
ha eközben tisztáznom kellene, most a geográfus vagy a történész énem munkálkodik-é, esetleg történeti-földrajzossá lényegülök-é át, ha Lika-Krbava vármegye századelős adataival bíbelödöm. A „örténeti regionális tudomány” müvelőjének lehetőségét már nem is említem. (Csak zárójelben ezt a „regionális tudományt” ,ragozni” sem könnyü!) Ha nincs jelentősége a tudomány-rendszertani huzakodásnak, akár ezzel zárhatnám is soraimat. De úgy vélem, minden újabb parcella elkülönülése a tudomány mezején csak nehezíti a dolgok egységben-látását, így erre csak ténylegesen indokolt esetben, helyzetben kellene sort keríteni.

Másodszorra ezért vesszük fel a kérdést: szükség volt-e - tudományelméleti szempontból - a regionális tudomány gründolására, különös tekintettel arra, hogy már volt a mezőnyben egy, - ab ovo és par excellente - a társadalmi mozgások térbeliségével foglalkozó tudományterület, a társadalmi földrajz. Ez a földrajz persze olyan volt, amilyen ... nem volt talán eléggé oknyomozó, nem tudta eredményeit kellö egzaktsággal prezentálni, képletekbe foglalni, az „általános” síkjára emelni, modellezni. (Habár a regionális tudományok legtöbb „modellje” second-hand áru!) Hunfalvy János geográfiája ma már meglehetősen száraz, olykor naiv, mindenképp „leíró”, de még Prinz „Magyar Földje” is alig vesz tudomást a társadalom bonyolultságáról, csak azt kutatja, hogy mily látható hatást gyakorolt környezetére. Ám a tudományok története a megújulások - „paradigma-váltások” - története s ez elmonđható a geográfia történetéröl is. Csak akkor állíthatjuk egy tudományterületről, hogy alkalmatlan feladata betöltésére, ez esetben nevezetesen a társadalomba zárt tér, térbeliség feltárására, magyarázatára, ha feltételezzük, hogy müvelöi genetikailag alkalmatlanok az újonnan jelentkezö igények, feladatok megoldására. İgy nagyon is kérdéses, hogy célszerú volt-e a meglévő „tértudomány” esetleges megújítása helyett új tudományágat kialakítani, megduplázni a „tértudományokat”. (Mai szemmel a múlt századi történettudomány is elég naivnak s „leírónak” tünik, a történeti folyamatokat e munkákban az uralkodók jelleme, a gonosz tanácsadók s a földöntúli hatalmak irányították - mégsem lépett a színre az idő-tudomány.) E „duplázás" nyomán persze fel kell tennünk a kérdést: mi a két tudományterület között a különbség? Mennyiben s miben ad többet vagy mást a regionális tudomány, mint a társadalomföldrajz, ha tárgyuk ugyanaz, a társadalom részét képezó térbeliség vizsgálata - s nem, mint mondani szokás, a társadalmi folyamatok „térbeli vetülete”! Lehet persze azt feltételezni, hogy a geográfia majd szerényen , leír”, a regionális tudomány pedig elemez, modellez, ő a gazdag rokon. Mert mi van, ha a geográfus túllépi a számára szabott határokat, sőt, tud-e csak „leírni” a geográfus? A következő pontban erre még visszatérek. Van regionális kutató, aki megengedően úgy véli, hogy a geográfia betölthet közismereti szerepet (TIT-elöadás: „Két hét vízi-biciklivel az Orinocon”), vagy lehet iskolai tantárgy, afféle Hármas Kis Tükör. Ha tehát felvállaljuk a tértudomány megduplázását, világossá kell tenni köztük a különbségeket (célkitủzésekben, más tudományágakhoz való viszonyban, kutatási terrénumokban, szemléletben, módszerekben, az ismeretanyag prezentációjában stb.). Ha e különbségtétel nem eléggé meggyőző, felvetődik: szükség van-e a kétféle tértudományra, célszerủ-e kettéválasztásuk, vagy ami ennél is perdöntőbb: létez-het-e egyáltalán a 
két tudományág egyidőben, egymás mellett. Megjegyzéseim harmadik csokra e kérdést is érinti.

Harmadszor: ha új tudományt ,teremtünk”, kötelességünk azt elhelyezni a tudományok rendszerében - akár tulajdonítunk jelentőséget e rendszernek, akár nem -, illetve tisztázni viszonyát a többi tudományággal, különösen, ha ezen új tudománynak eleve ,interdiszciplináris” illata van, különösen, ha tudjuk, hogy a legtöbb társadalomtudomány maga is vizsgálja tárgyának területi vonatkozásait, különösen, ha nyilvánvaló, hogy építeni óhajt e tudományágak ismeretanyagából. E nélkül az „új” tudománynak nincs önmeghatározása, szerepzavarba kerül, mindennapi munkájában is zavarok mutatkozhatnak, s félreértések adódhatnak e társtudományok (?) „vonatkozásában”. Mert vitathatatlan, hogy pl. a szociológiának a területi érdeklődése nem lebecsülendö - falu- és városszociológia, szegregáció-kutatás, városökológia, városszerkezeti modellek készítése stb.! -, csakúgy, mint a közgazdaságtané - területi gazdaságtan! -, a társadalom- és gazdaságtörténet is egyre nagyobb figyelmet fordít a regionális történésekre, sőt még az irodalom, meg az irodalomtudomány sem érintetlen, gondoljunk Szabó Zoltán „Szerelmes földrajzára”, melynek olvasása az Alföld megismeréséhez-átéléséhez nem kevés segítséget adhat.

Milyen lehet tehát a viszonya e tudományágaknak s a regionális tudománynak? Sokféle. Induljunk tehát ki abból, hogy a társadalomtudomány tortájának szeleteit adó tudományágak maguk is foglalkoznak „területi kérdésekkel”. Ezt próbálom szemléltetni az alábbi kis rajzzal:

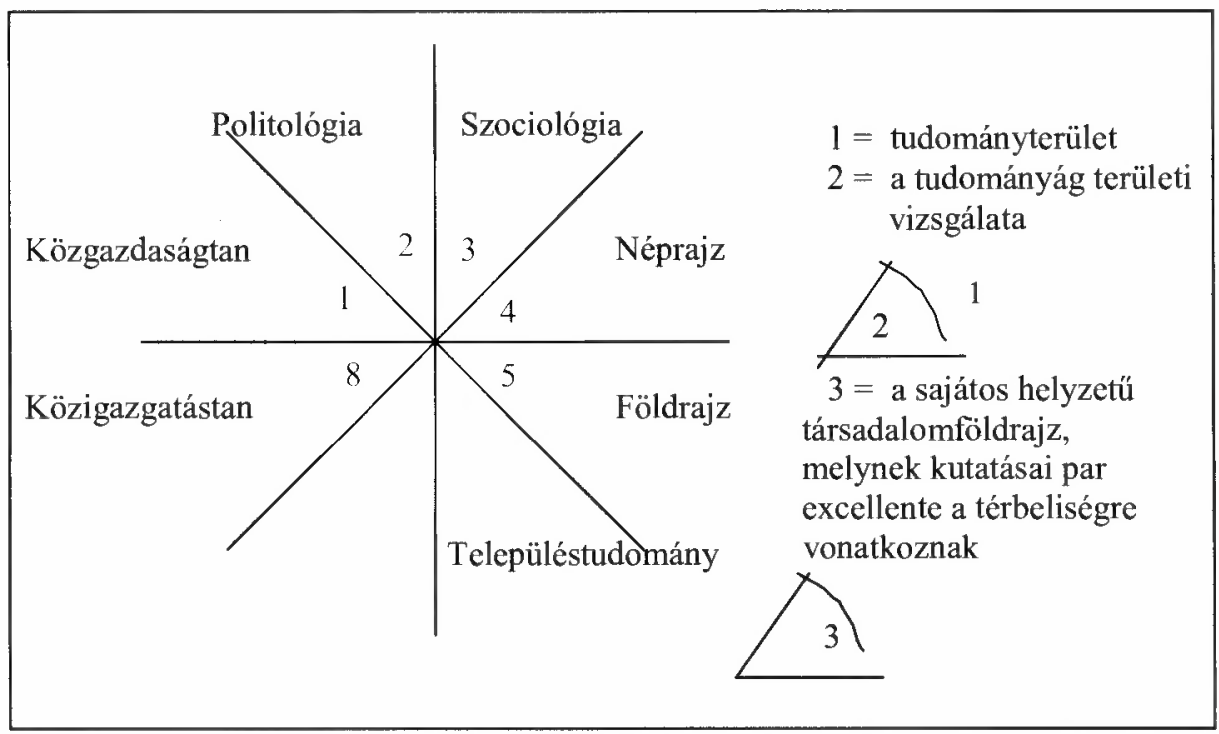


A) Az első lehetséges „viszonyt” szemléltesse a következő ábra:

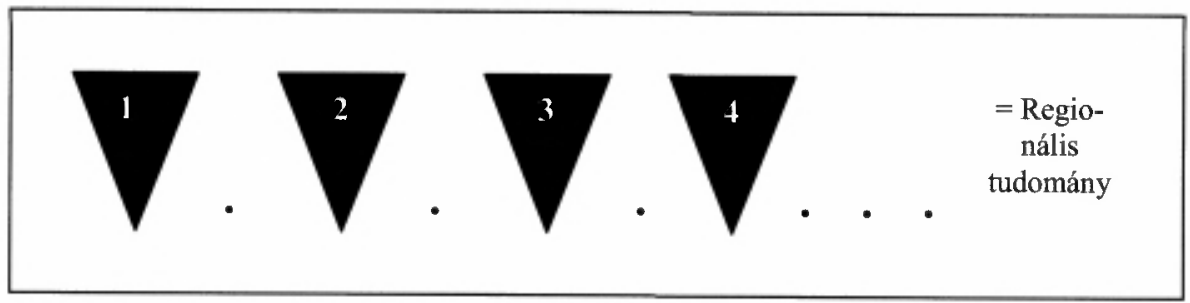

E felfogás szerint, tehát ha valamely társadalomtudományban - szociológia, politológia, közgazdaságtan, közigazgatástan stb. - területi vizsgálatok folynak, e vizsgálatok eredménye automatikusan a regionális tudomány részévé válik, $\mathrm{s}$ e tudományágak „területiségével” rendszeresebben foglalkozó kutató regionális kutatóvá válik anélkül, hogy hátat fordítana „eredeti” szakmájának. Az, hogy ezen értelmezés nem nélkülözi a realitást, mutatja: a magyar tudományos életben is jó néhány ilyen „kétlaki” kutató tevékenykedik, ha ki is mutatható némi distancia az „echte” regionalisták s a „gyöttmentek” között. (Kérdés: mi történik, ha akadémikusi kontingenseket kell szétosztani a két csoport között?) E felfogást, amely szerint „,csak” területi témát kell müvelni, s ettổl valami vagy valaki regionális tudománnyá ill. tudóssá válik - függetlenül más „viszonyulásoktól” - , izolazionista” felfogásnak nevezhetjük.

B)

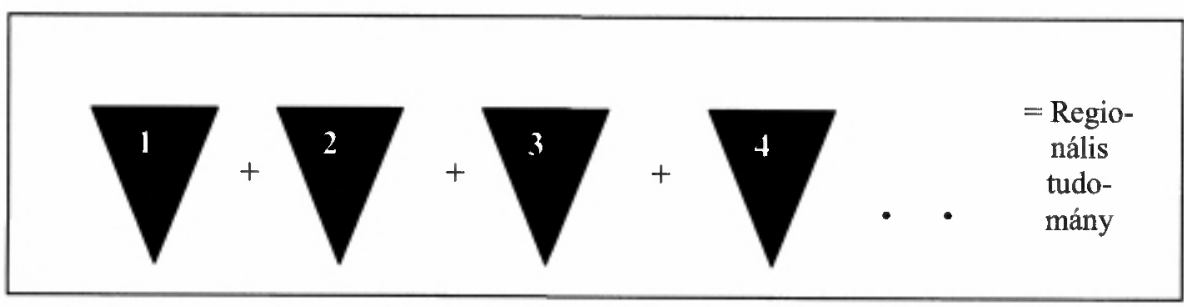

A második lehetséges felfogás szerint a különféle tudományágakban született területi vizsgálatok összessége adja a regionális tudományt. Természetesen az "addatív" értelmezés szerint felépített regionális tudomány nem egyszerü „összeadást" jelent, hanem gondolatok cseréjét, közös kérdésfelvetést, közös célkitüzéseket, esetleg általánosítást, közös értékelést stb., vagyis az összegzett eredmények magasabb szintre emelését. Ezen értelmezés sem elméleti konstrukció, cégünk, az RKK jórészt ily metódus szerint dolgozik. Ez a felfogás feltételezi, hogy a regionális tudomány "többszakmás" interdiszciplína, amelyen belül müvelöi többékevésbé megtartják eredeti szakmájukat. 
C)

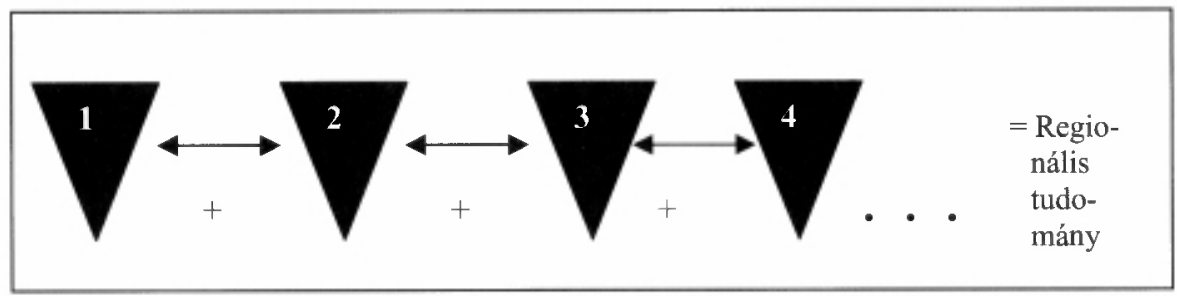

A regionális tudomány ,integratív" felfogása szerint az egyes területi vizsgálati eredmények nem egyszerủen összegződnek, hanem a különbözö tudományágak szoros együttmüködése nyomán születnek, közös célok kitüzése nyomán, egymás eredményeit magyarázó okként is használva, „korrelációkat” keresve, a fogalmak használatában konszenzusra - vagy legalábbis a csereszabatosságig - jutva és így tovább. Ilyen „együttkutatás” során az egyes eredmények, módszerek és kutatók „hovatartozása” (,szakmája”) el is veszítheti jelentőségét. Az eredmények általánosítása, „komplex" modellbe foglalása, magasabb szintre emelése ilyen konstellációban elvárható. Nly megközelítésben az általánosítás oly szintjére juthatunk, amin pl. a modernizáció területi differenciáit vizsgálva a régiókat a „ligaturákkal sújtott”, a tradicionalista vagy a konzervatív jelzőkkel is illethetjük.

D) A következő „lépcsőn” a regionális tudomány öntörvényüen létezik; elkülönülten létezik „saját" célkitủzésekkel, szemlélettel, ismeretanyaggal (melyet lehet, hogy más tudományágakból „desztillál” a maga számára), módszerekkel, önálló fogalomhasználattal, törvényszerüségekkel és így tovább. Ekkor sem izolálódik a társadalomtudományok területi szektoraitól, de azokat szervesen magába olvasztja - el is szakítván eredeti közegétől -, vagy irányítása alá vonja azokat, „megrendelöjükké” válik. Produktumaikat nem szintetizálja, hanem átemeli, miközben saját „rendszerén" - szemlélet, módszerek, fogalmak stb. - át is szüri. Az efféle regionális tudományban a karmesteri pálca a regionalistáké, s legfeljebb „Janus-arcú” kutatók müvelhetik még, akik ugyan specialistái lehetnek egy-egy szakterületnek - közigazgatástan, szociológia, közgazdaságtan stb. -, de tökéletesen bírniuk kell a regionális tudomány teljes kelléktárát. (,,Domináns" értelmezés.) 


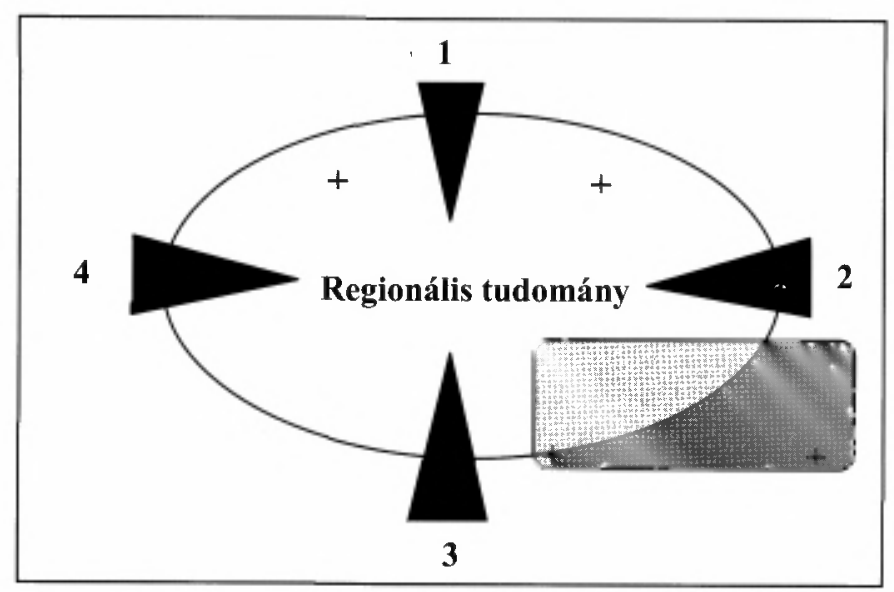

E) Végül elképzelhető oly „erös” és „kifejlett” regionális tudomány, amely teljesen a „saját lábán áll”, s a többi tudományág az adat- és információ-szolgáltató szerepét tölti be. (Elképzelhető, de nem valószínú változat.)

A világ - hál' istennek - nem szorítható klisébe, de egy tudományterület gründolásakor a fenti „,viszonyulásokat” számba kell venni, velük kapcsolatban állást foglalni, következményeit levezetni”.

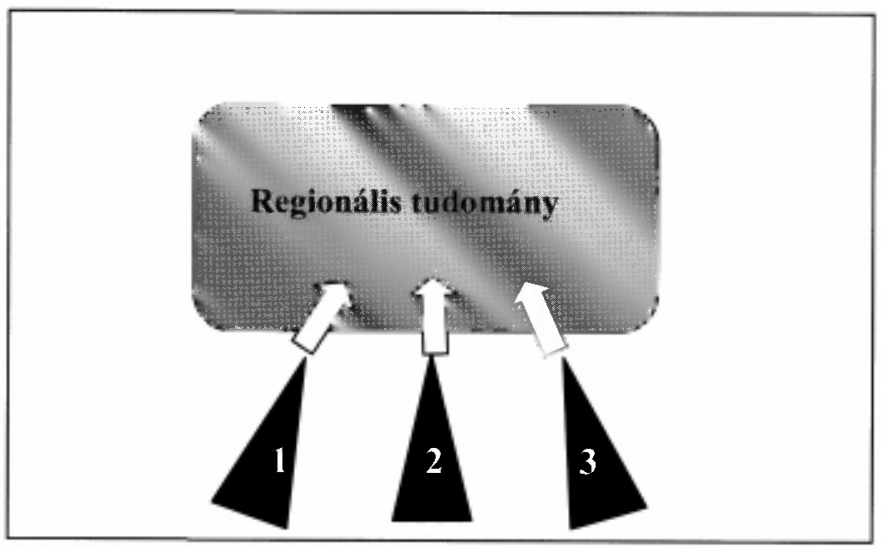

$\mathrm{S}$ most visszatérve a második pontunkhoz, a geográfia és a regionális tudomány viszonyához: Hol van a helye a társadalomföldrajznak a fenti „modellekben”? Hogyan illeszthető a tudományterületek fent vázolt „,viszonylataiba”? Hát nem nagyon. Ugyanis: a geográfia teljes produktuma területi jellegü, vagyis a fenti „modellek” a geográfiát mindenestöl „,beemelik” a regionális tudományba (legalábbis az A-D esetekben). Ez esetben nem is lehet duplázódás, bármely modell választása - a regionális tudomány részéról - implicite a geográfia felfalását is jelenti. A területi tudományok megduplázása nem csak hogy nem célszerú, ezek szerint nem is lehetséges. Emellett 
csak mellékes probléma, hogy a geográfia is használja más tudományágak eredményeit - egyetlen falu földrajzi vizsgálata sem mellőzheti pl. a demográfia, a szociológia [miért és hova költözik el a falubeli?], az agrárgazdaságtan stb. eredményeit -; így aztán kérdéses pl., hogy a „magas szintü tudományos eredményeket átvéve”, hogy tudja azt a „saját nyelvére fordítva” egyszerủ leírássá lúgozni (a „,öldrajz maradjon a kaptafánál” - a leírásnál szlogen tarthatatlansága). De még a „bekebelezéselméletet" tagadva sem lehet a földrajzot a maga szatelit rendszerével egyetemben könnyüszerrel beilleszteni valamely prezentált modellbe.

(Csakhogy még némi töprengeni-valóval szolgáljak a regionalistáknak: mi a helyzet a településtudománnyal, már ha van ilyen? Szinte ugyanaz elmondható erröl a tudományterületről is, ami a regionális tudományról. Majdhogynem ugyanabból élnek - kicsit több múszaki tudományból s némi múvészetből-esztétikából -, ugyanúgy „viszonyulhatnak” a többi tudományághoz, de minő a kapcsolatuk a regionális tudománnyal? Pl. ténykedik tudományos életünkben olyan kutató, aki szociológus képzettsége-munkahelye mellett az MTA regionális tudományos és településtudományi bizottságának a tagja!)

Máshogy vetődik fel a kérdés a „gyakorlat mezején”! Praktikus okokból jó, ha van, lesz regionális tudomány is. Egy ,új” tudomány új pályát, pályákat jelent... tudományos bizottság, kuratóriumok, egyetemi tanszékek, pályadíjak... s a kétségtelen vonzó végcél: a regionális tudomány levelezö tagja! $\mathrm{Na}$, hát ezt tényleg nem kínálja a geográfia! Kedves B, át kellene igazolni?

Budapest, 2000 májusa

Ölel: Beluszky Pál

P. S. I.: Jutott eszembe, nem lapoztam át levelem írása előtt újólag G. Benko füzetét a regionális tudományról. Megtettem. Nem kellett újrafogalmaznom fenti soraimat.

P. S. II.: Utolsó, utólagos (!) megjegyzés 2008-ból: talán többre megyünk ketten - a geográfia és a regionális tudomány -, együtt! 